\title{
Separate cloning and expression analysis of two protein components of 4-chlorobenzoate dehalogenase from Pseudomonas sp. C8S3
}

\author{
ANGelika Elsner, ${ }^{1}$ Rudolf Muller ${ }^{2 *}$ and Franz Lingens ${ }^{1}$ \\ ${ }^{1}$ Institut für Mikrobiologie der Universität Hohenheim, Garbenstrasse 30, D-7000 Stuttgart 70, Germany. \\ ${ }^{2}$ TU Hamburg-Harburg, AB Biotechnologie II, Harburger Schlossstrasse 37, D-2100 Hamburg 90, Germany.
}

(Received 5 September 1990; revised 4 November 1990; accepted 14 November 1990)

\begin{abstract}
The two protein components, II and III, of the 4-chlorobenzoate dehalogenase from Pseudomonas sp. CBS3 were cloned separately into Escherichia coli. Component II was obtained on plasmid pCBSII, containing a 3.0 kbp HindIII fragment, and component III on plasmid pCBSIIIb, containing a $1.3 \mathrm{kbp}$ SaIIPstI fragment. The identities of the two components were confirmed by comparison with the authentic components from Pseudomonas sp. CBS3. Both components were expressed constitutively in $E$. coli. Neither component alone showed dehalogenating activity. Only in the mixture of crude extracts from both clones was 4-chlorobenzoate dehalogenase detectable. The specific activities in $E$. coli crude extracts were $2.9 \mathrm{mU}$ (mg protein) ${ }^{-1}$ for component II and $3.5 \mathrm{mU}$ (mg protein) ${ }^{-1}$ for component III. Expression analysis by minicell experiments revealed a single polypeptide chain of $29 \mathrm{kDa}$ for component II and of $31 \mathrm{kDa}$ for component III.
\end{abstract}

\section{Introduction}

Chlorinated benzoic acids are intermediates in the biodegradation of chlorinated biphenyls (Furukawa et $a l ., 1978)$ and herbicides (Köcher et al., 1976). Several bacteria with the ability to utilize 4-chlorobenzoate as sole source of carbon and energy have been isolated (Ruisinger et al., 1976; Klages \& Lingens, 1979, 1980; Zaitsev \& Karasevich, 1981 ; van den Tweel et al. 1986; Marks et al., 1984a). The initial step in 4-chlorobenzoate catabolism by these bacteria is the replacement of the chlorine substituent by a hydroxy group. Müller $e t$ al. (1984) and Marks et al. (1984b) showed that the oxygen in the enzymically formed 4-hydroxybenzoate was derived from water and that molecular oxygen was not necessary for the reaction. The 4-chlorobenzoic acid dehalogenase from Pseudomonas sp. CBS3 has been cloned on a $9.8 \mathrm{kbp}$ fragment (Savard et al., 1986). From deletion experiments it was suggested that this whole fragment was necessary for the expression of dehalogenating activity. Here we present evidence that only two closely linked much smaller DNA fragments, each expressing a single polypeptide chain, are necessary for this reaction.

\section{Methods}

Bacterial strains, plasmids and growth conditions. The bacteria and plasmids used in this study are listed in Table 1. E. coli strains were grown at $37^{\circ} \mathrm{C}$ in L-broth (Maniatis et al., 1982), containing $100 \mu \mathrm{g}$ ampicillin $\mathrm{ml}^{-1}$ when appropriate. Pseudomonas sp. CBS3 was grown at $30^{\circ} \mathrm{C}$ as described by Klages \& Lingens (1979) on mineral salts medium containing $2 \mathrm{mM}-4$-chlorobenzoate.

Isolation of DNA and cloning procedures. Preparative amounts of plasmid DNA were prepared by the method of Birnboim \& Doly (1979) with subsequent purification of the DNA by $\mathrm{CsCl}$ density-gradient centrifugation. For analytical purposes plasmids were isolated by the method of Holmes \& Quigley (1981). Subcloning and restriction mapping were accomplished by established techniques (Maniatis et al., 1982). DNA fragments were eluted from $0.7 \%$ agarose gels by the freeze-squeeze method of Tautz \& Renz (1983). The ligated constructs were used to transform $E$. coli TG1 by the calcium chloride method (Mandel \& Higa, 1970).

Preparation of crude extracts. E. coli cells were grown overnight in 1 litre of $\mathrm{L}$-broth containing ampicillin. After centrifugation at $4{ }^{\circ} \mathrm{C}$ and $4000 \mathrm{~g}$ for $10 \mathrm{~min}$, the cells were resuspended in $3 \mathrm{ml} 50 \mathrm{mM}$-potassium phosphate buffer $\mathrm{pH} \mathbf{7 . 0}$ and were passed twice through a French pressure cell at $35 \mathrm{MPa}$. Cell debris was removed by centrifugation at $4^{\circ} \mathrm{C}$ and $40000 \mathrm{~g}$ for $30 \mathrm{~min}$.

Enzyme assay. 4-Chlorobenzoate dehalogenase activity was assayed by quantitative thin-layer chromatography as described before (Thiele et al., 1987). For activity tests with single components, the other components were added in excess.

Enrichment of the two cloned components of 4-chlorobenzoate dehalogenase from $E$. coli crude extracts. Crude extracts from $E$. coli clones, containing the cloned components of the 4-chlorobenzoate dehalogenase, were heated to $55^{\circ} \mathrm{C}$ for $5 \mathrm{~min}$. The resulting precipitates were removed by centrifugation at $4{ }^{\circ} \mathrm{C}$ and $40000 \mathrm{~g}$ for $30 \mathrm{~min}$. The supernatants were then brought to $45 \%$ saturation with solid $\left(\mathrm{NH}_{4}\right)_{2} \mathrm{SO}_{4}$. After centrifugation the resulting pellets were dissolved in $3 \mathrm{ml} 50 \mathrm{~mm}$-potassium phosphate buffer $\mathrm{pH} 7.5$ and applied to a Sephadex G150 column $(2.5 \times 100 \mathrm{~cm})$. Proteins were eluted from the column with the same buffer. Fractions were collected and assayed for protein at $280 \mathrm{~nm}$ and tested for 4-chlorobenzoate dehalogenating activity. 
Table 1. Bacterial strains and plasmids used in this study

\begin{tabular}{lll}
\hline \hline Strain or plasmid & \multicolumn{1}{c}{ Phenotype } & \multicolumn{1}{c}{ Reference } \\
\hline Pseudomonas sp. CBS3 & 4-chlorobenzoate dehalogenase & Klages \& Lingens (1979) \\
E. coli TG1 & LacZ $^{-}$ & Gibson (1984) \\
E. coli DS910 & Minicell strain; RecA- derivative of strain DS410 $^{-}$ & Dougan \& Sherratt (1977) \\
pUC18 & $\mathrm{Ap}^{r}$ & Vieira \& Messing (1977) \\
pPSA 843 & $\mathrm{Ap}^{\mathrm{r}}$, 4-chlorobenzoate dehalogenase & Savard et al. (1986) \\
pCBSII & $\mathrm{Ap}^{\mathrm{r}}$ & This study \\
pCBSIII & $\mathrm{Ap}^{\mathrm{r}}$ & This study \\
pCBSIIIb & $\mathrm{Ap}^{\mathrm{r}}$ & This study \\
\hline \hline
\end{tabular}

Hybridization experiments. Chromosomal DNA from Pseudomonas sp. CBS3 and plasmid DNA of pCBSII and pCBSIII were digested with HindIII or SaII and loaded on an agarose gel. DNA was blotted from the gel as described by Southern (1975) on a NY3N Nytran membrane (Schleicher \& Schüll). The filter was hybridized with a nicktranslated, biotinylated probe of pCBSII (Schneider \& Müller, 1988). The nick-translation kit was purchased from Gibco Bethesda Research Laboratories; the biotin-16-dUTP was from Boehringer.

Identification of the gene products of the cloned fragments. For the identification of the protein products from the $E$. coli clones expressing component II and component III, we performed minicell experiments with strains harbouring pCBSII and pCBSIIIa according to Dougan \& Sherratt (1977). $\left.{ }^{35} S\right]$ Methionine was purchased from Amersham.

\section{Results}

Separate cloning of the two components of 4chlorobenzoate dehalogenase from Pseudomonas sp. CBS3

Savard et al. (1986), who cloned the 4-chlorobenzoate dehalogenase from Pseudomonas sp. CBS3, suggested from their deletion experiments that all of the $9.8 \mathrm{kbp}$ fragment was necessary for the dehalogenation reaction, and that the dehalogenase had to comprise several protein subunits. We therefore digested this $9.8 \mathrm{kbp}$ insert with various restriction enzymes and ligated the fragments obtained into the plasmid pUC18 (Vieira \& Messing, 1982). All of these subclones were grown in 1 litre cultures and crude extracts were prepared. As expected, none of these extracts showed dehalogenating activity. However, when the extracts of two clones, one containing a $3 \mathrm{kbp}$ HindIII fragment (pCBSII) and the other containing a $2.6 \mathrm{kbp} \mathrm{Sall}$ fragment (pCBSIIIa), were mixed, dehalogenating activity was observed. The $2.6 \mathrm{kbp} S a l$ fragment could be further shortened by digestion with PstI to $1.3 \mathrm{kbp}$ (pCBSIIIb). The subcloning procedure is outlined in Fig. 1.
Identification of the dehalogenase components encoded in the subclones

In previous biochemical studies, we found that 4chlorobenzoate dehalogenase from Pseudomonas sp. CBS3 comprised at least three different components (Elsner et al., 1991). Components II and III were stable proteins, whereas component I was an unstable small molecule. When we mixed crude extract from the clone containing pCBSII with the enriched components of 4chlorobenzoate dehalogenase from Pseudomonas sp. CBS3, only component III had to be added to restore dehalogenating activity. To crude extracts of the pCBSIII-containing clone only component II had to be added for activity. We therefore concluded that pCBSII encoded component II, whereas pCBSIIIa and pCBSIIIb coded for component III. The small component I seemed to be present in both extracts. However, when we used crude extracts from $E$. coli containing no plasmid at all, this extract also substituted for component I. Upon dialysis the extracts lost the ability to substitute for component I. We therefore concluded that component I was a small cofactor common in crude extracts of $E$. coli, which was not necessarily encoded in the two plasmids. In order to confirm the identities of the two cloned components, we partially purified the components from the crude extracts of the clones by heat treatment and ammonium sulphate precipitation. In these purification steps the component expressed from pCBSII behaved identically to component II and that from pCBSIII to component III of the 4-chlorobenzoate dehalogenase from Pseudomonas sp. CBS3. In gel filtration experiments on Sephadex G150 the two components comigrated with the authentic components from Pseudomonas sp. CBS3 at molecular masses of 86 $\mathrm{kDa}$ and $92 \mathrm{kDa}$, respectively. The activity of component II in extracts of $E$. coli containing pCBSII was $2 \cdot 9$ $\mathrm{mU}$ (mg protein) $)^{-1}$, whereas the activity of component 


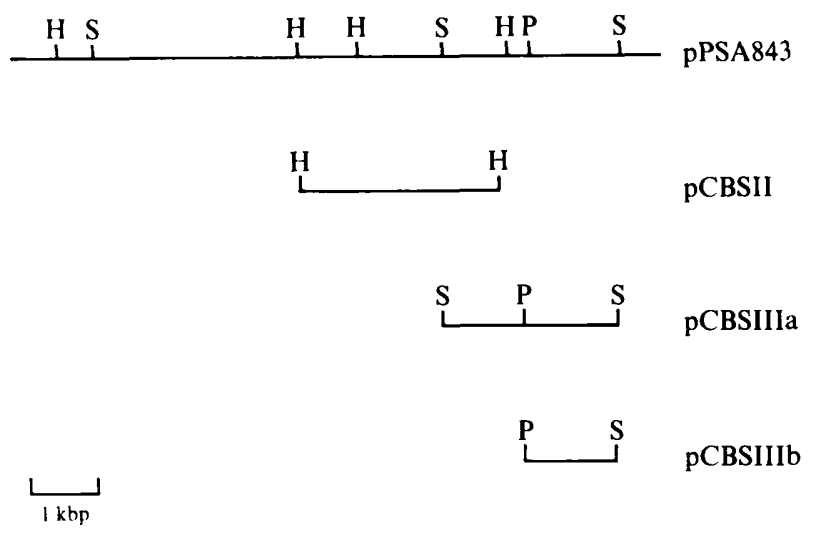

Fig. 1. Subcloning strategy of the $9.8 \mathrm{kbp}$ insert encoding 4chlorobenzoic acid dehalogenase from pPSA843. pCBSII encodes component II, pCBSIIIa and pCBSIIIb encode component III. H, HindIII; P, PstI; S, SalI.

III in the crude extracts of pCBSIIIa containing $E$. coli clones was $3.5 \mathrm{mU}$ (mg protein) ${ }^{-1}$. Both components were expressed constitutively in their clones.

\section{Expression analysis of the cloned fragments by minicell experiments}

In order to determine the size and number of polypeptide chains encoded in the cloned fragments, we performed minicell experiments according to Dougan \& Sherratt (1977). The radioactively labelled gene products were detected by autoradiography after separation by SDSpolyacrylamide gel electrophoresis. In both clones only a single polypeptide was expressed from the DNA insert (Fig. 2). pCBSII coded for a $29 \mathrm{kDa}$ polypeptide, whereas the polypeptide from pCBSIIIa was $31 \mathrm{kDa}$.

\section{Restriction analysis and hybridization experiments}

The restriction maps obtained from the two inserts (Fig. 1) suggested that the inserts from pCBSII and pCBSIIIa contain overlapping sequences. We therefore labelled the insert of pCBSII and performed Southern analysis on pCBSIIIa and Pseudomonas CBS3 chromosomal DNA. As shown in Fig. 3, the insert from pCBSIIIa hybridized with that from pCBSII. In the HindIII digests of chromosomal DNA from Pseudomonas CBS3 the two expected bands corresponding to the insert of pCBSII hybridized, whereas in the SalI digests the band corresponding to the insert of pCBSIIIa hybridized, together with a second band at about $4.4 \mathrm{~kb}$, containing the non-overlapping parts of the insert from pCBSII. From these results it is clear that the inserts from pCBSII and pCBSIIIa contained identical sequences.

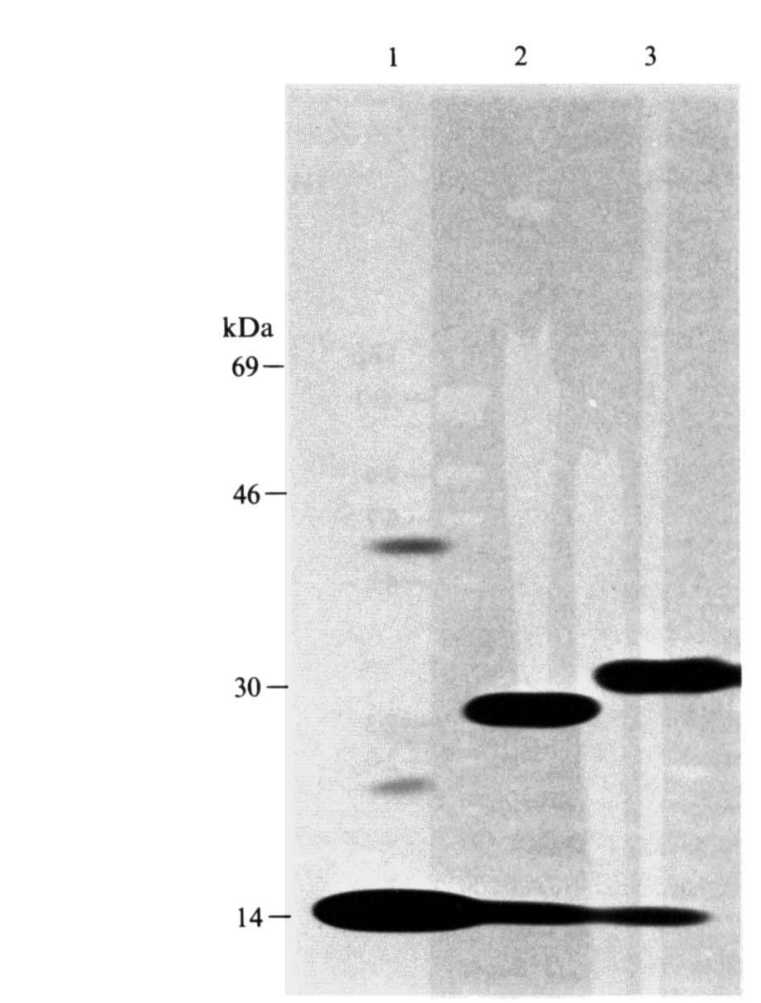

Fig. 2. SDS-polyacrylamide gel electrophoresis of minicell extracts. Lane 1, pUC18; lane 2, pCBSII, which contains a $3.0 \mathrm{kbp}$ insert coding for component II of 4-chlorobenzoate dehalogenase; lane 3, pCBSIIIa, which contains a $2.6 \mathrm{kbp}$ insert coding for component III of 4chlorobenzoate dehalogenase. The molecular masses of the standards used are indicated on the left.

Substitution of component I by ATP, coenzyme A and $\mathrm{Mg}^{2+}$

Recent results of F. Löffler (unpublished) suggested that in the reaction of 4-chlorobenzoate dehalogenase from Pseudomonas CBS 3 component I could be replaced by a mixture of ATP, coenzyme A and $\mathrm{Mg}^{2+}$. When we used mixtures of dialysed inactive extracts from $E$. coli clones containing pCBSII and pCBSIIIb, the addition of $1 \mathrm{~mm}$ ATP, $1 \mathrm{~mm}$-coenzyme $\mathrm{A}$ and $1 \mathrm{mM}-\mathrm{MgSO}_{4}$ restored the dehalogenating activity.

\section{Discussion}

The two protein components of 4-chlorobenzoate dehalogenase have been cloned and expressed separately in $E$. coli. Both components were expressed constitutively, which indicates that they are under negative control in the parent strain and that the regulatory sequences have not been cloned. In the original clone pPSA843 (Savard et al., 1986) as well as in several clones we obtained from a genomic library we constructed from Pseudomonas sp. 


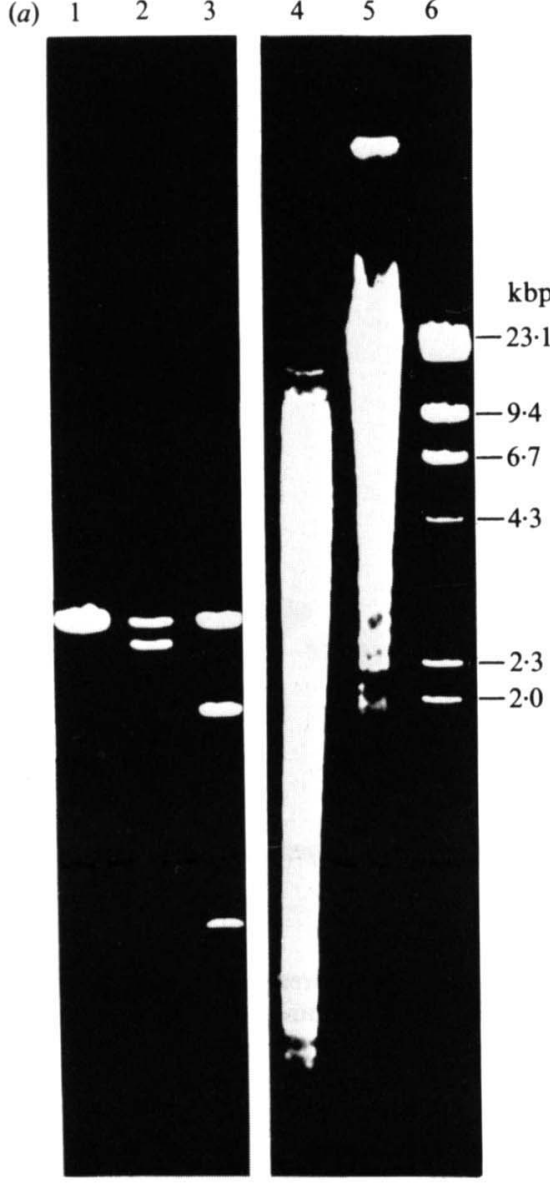

CBS3 (A. Elsner, unpublished results) both components were also expressed constitutively, which is in contrast to Pseudomonas sp. CBS3, where the expression of the enzyme is regulated by 4-chlorobenzoate. Since some of these clones contained inserts of more than $30 \mathrm{kbp}$ the regulatory sequences must be located far from the structural genes. Another explanation might be that these regulatory sequences were not functional in $E$. coli.

The structural genes of the two components must be closely linked, as evidenced by the overlapping sequences in the clones expressing the two components. From these data it is clear that for the constitutive expression of 4-chlorobenzoate dehalogenase in $E$. coli only a much smaller DNA fragment was necessary than was originally suggested (Savard et al., 1986).

None of the 4-chlorobenzoate dehalogenases described so far has been purified to homogeneity. Therefore, nothing is known about the subunit structure of the components involved in the dehalogenation reaction. From the gel filtration experiments and from the minicell experiments, we suggest that component II and component III are both comprised of three identical protein subunits.
Fig. 3. Southern blotting and hybridization of pCBSII, pCBSIIIa and chromosomal DNA from Pseudomonas sp. CBS3 with biotinylated pCBSII insert DNA. (a) Agarose gel used for Southern blotting; $(b)$ Southern blot with biotinylated pCBSII as probe. Lanes: 1, plasmid DNA from pUC18 digested with HindIII; 2, plasmid DNA from pCBSIIIa digested with $S a I I ; 3$, plasmid DNA from pCBSII digested with HindIII; 4, DNA from Pseudomonas sp. CBS3 digested with Sall; 5, DNA from Pseudomonas sp. CBS3 digested with HindIII; 6, HindIII digested $\lambda$-DNA.
The small unstable component I could be replaced by a mixture of coenzyme A, ATP and $\mathrm{Mg}^{2+}$. The biosynthesis of these compounds is not located on the DNA fragments of the clones showing dehalogenating activity but the general availability of these compounds in crude extracts makes the dehalogenation reaction possible when the two protein components described above are expressed.

We thank Dr I. Hunter, Department of Genetics, University of Glasgow, UK, for supporting the minicell experiments in his laboratory. This work was supported by the Bundesministerium für Forschung und Technologie under the contract 0319416A and by Fonds der Chemischen Industrie.

\section{References}

Birnboim, H. C. \& Doly, J. (1979). A rapid alkaline extraction procedure for screening recombinant plasmid DNA. Nucleic Acids Research 7, 1513-1523.

Dougan, G. \& SherRaTT, D. (1977). The transposon Tnl as a probe for studying ColEl structure and function. Molecular and General Genetics 151, 151-160. 
Elsner, A., Löffler, F., Miyashita, K., Müller, R. \& Lingens, F. (1991). Resolution of 4-chlorobenzoate dehalogenase from Pseudomonas sp. strain $\mathrm{CBS} 3$ into three components. Applied and Environmental Microbiology 57 (in the Press).

Furukawa, K., Tonumura, K. \& Kamibayashi, A. (1978). Effect of chlorine substitution on the biodegradability of polychlorinated biphenyls. Applied and Environmental Microbiology 35, 223-227.

Gibson, T. J. (1984). Studies on the Epstein-Barr virus genome. PhD Thesis, University of Cambridge, UK.

Holmes, D. S. \& Quigley, M. (1981). A rapid boiling method for the preparation of bacterial plasmids. Analytical Biochemistry 114, 193197.

KLAGES, U. \& LingENS, F. (1979). Degradation of 4-chlorobenzoic acid by a Pseudomonas spec. Zentralblatt für Bakteriologie, Parasitenkunde, Infektionskunde und Hygiene Abteilung Originale C1, 215-223.

KLAGES, U.\& LINGENS, F. (1980). Degradation of 4-chlorobenzoic acid by a Nocardia species. FEMS Microbiology Letters 6, 201-203.

KöCHER, H., LingeNs, F. \& KoCH, W. (1976). Untersuchungen zum Abbau des Herbizids Chlorphenpropmethyl in Boden und durch Mikroorganismen. Weed Research 16, 93-100.

MANDEL, M. \& HigA, A. (1970). Calcium dependent bacteriophage DNA infection. Journal of Molecular Biology 53, 159-162.

Maniatis, T., FritSCh, E. F. \& SAMBrook, J. (1982). Molecular Cloning, a Laboratory Manual. Cold Spring Harbor, NY: Cold Spring Harbor Laboratory.

Marks, T. S., SMITH, A. R. W. \& QuiRK, A. V. (1984a). Degradation of 4-chlorobenzoic acid by Arthrobacter spec. Applied and Environmental Microbiology 48, 1020-1025.

Marks, T. S., Wait, R., SMith, A. R. W. \& Quirk, A. V. (1984b). The origin of the oxygen incorporated during the dehalogenation/hydroxylation of 4-chlorobenzoate by an Arthrobacter sp. Biochemical and Biophysical Research Communications 124, 669-674.
MülLeR, R., THIELE, J. \& LINGENS, F. (1984). Incorporation of ${ }^{18} \mathrm{O}$ water into 4-hydroxybenzoic acid in the reaction of 4-chlorobenzoate dehalogenase from Pseudomonas sp. CBS3. Biochemical and Biophysical Research Communications 124, 178-182.

Ruisinger, S., KlaGes, U. \& Lingens, F. (1976). Degradation of 4chlorobenzoic acid by an Arthrobacter species. Archives of Microbiology 110, 253-256.

Saviard, P., Peloquin, L. \& Sylvestre, M. (1986). Cloning of Pseudomonas sp. strain CBS3 genes specifiying dehalogenation of 4chlorobenzoate. Journal of Bacterioloay 168, 81-85.

SCHNEIDER, J. \& MÜLLER, L. (1988). DNA-DNA-Hybridisierung mit biotinylierten DNA-Sonden. Forum Mikrobiologie 6, 254-262.

SOUTHERN, E. (1975). Detection of specific sequences among DNA fragments separated by gel electrophoresis. Journal of Molecular Biology 98, 503-517.

TAUTZ, D. \& RENZ, M. (1983). An optimized freeze-squeeze method for the recovery of DNA fragments from agarose gels. Analytical Biochemistry 132, 14-19.

THIELE, J., MüLLER, R. \& LINGENS, F. (1987). Initial characterisation of 4-chlorobenzoate dehalogenase from Pseudomonas sp. CBS3. FEMS Microbiology Letters 41, 115-119.

VAN DEN TWEeL, W. J. J., TER BURG, N., KOK, J. B. \& DE BONT, J. A. M. (1986). Biotransformation of 4-hydroxybenzoate from 4-chlorobenzoate by Alcaligenes denitrificans NTB-1. Applied Microbiology and Biotechnology 25, 289-294.

VIeIRA, J. \& Messing, J. (1982). The pUC plasmids, an M13mp7derived system for insertion mutagenesis and sequencing with synthetic universal primers. Gene 19, 259-268.

ZAITSEV, G. M. \& KARASEVICH, YU. N. (1986). Preparative metabolism of 4-chlorobenzoic acid in Arthrobacter globiformis. Mikrobiologiya $50,423-428$. 